\title{
アルカリ骨材反応をめぐって
}

\author{
小林一輔十内川浩十筒英雄
}

（東京大学生産技術研究所）（小野田セメント中央研究所）（竹中工務店技術研究所）

[小林］本日は，最近わが国において問題になってお りますアルカリ骨材反応について，お話を同いたいと思 います。

まず，お断りしておきますが，この問題は各分野，業 界にそれぞれ複雑な反響を呼び起こしておりますので， 本日ご出席の内川さんと高さんには，それぞれの業界の 意向を代弁するということではなくて，あくまでこの問 題について調查研究を進めてこられた，いってみれば個 人としての立場で自由にお話しいただきたいと思いま す。

コンクリートがこの世に出てきて以来, だいぶ長い 間, 骨材といらものは不活性であって化学反応とは無縁 のものであると考えられてきたわけですが, 1940 年, ア メリカの Stanton が，アルカリ骨材反応について世界で 初めて報告して以来, 骨材程度の差こそあれ, 大抵の ものはコンクリート中において何らかの化学的な変化を 受けるものだということが分かってきたわけです。

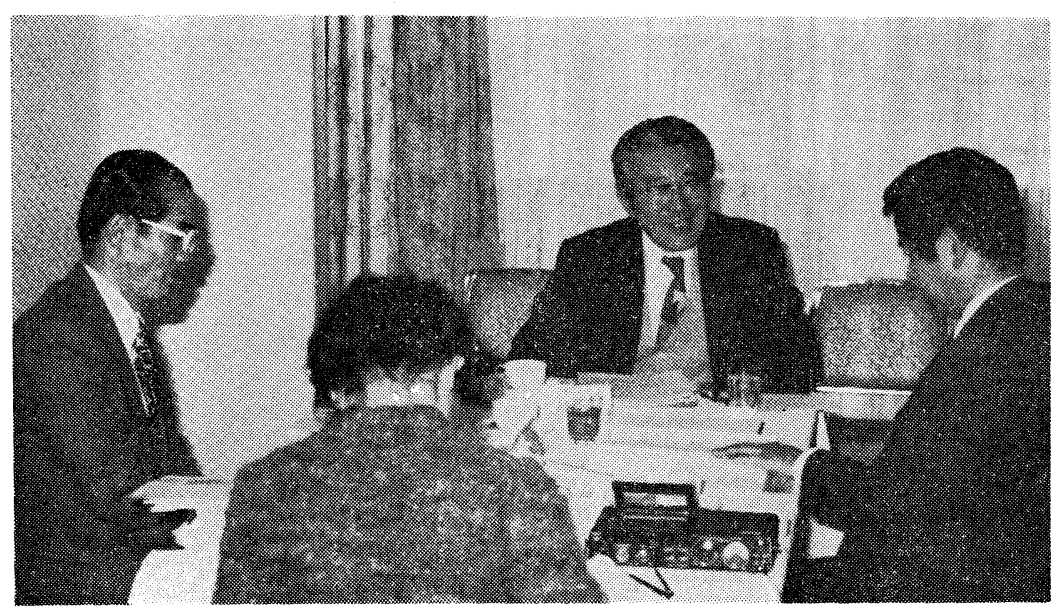

左から, 内川浩氏, 小林一輔氏, 嵩英雄氏
こういう意味では，アルカリ骨材反応による劣化がわ が国において発生しても，ベつに驚くには当たらないと 思いますが，ただ日本の場合は，ほとんど無防備状態の ところに出てきたといらことで波紋が大きく，また誤っ た見方も流されたりしているんだと思います。

きょうは, 少しこの辺の状況も踏まえて, アルカリ骨 材反応について取り上げてみたいと思います。

まず，骨材が主な原因でコンクリートが劣化するケー スがいくつかありますが，その中で，いわゆるアルカリ 骨材反応といらものはどこが違うのか, アルカリ骨材反 応の定義のようなことについて, 内川さんから伺いたい と思います。

\section{○ アルカリ骨材反応とは}

[内川 アルカリ骨材反応という言葉は非常に広範囲 な意味に用いられていて，アルカリ骨材反応とアルカリ 骨材反応によるコンクリートの劣化とを含めた意味に用 いられております。厳密な意 味ではモルタルあるいはコン クリートの中にある骨材とア ルカリとの反応をいいます。

このアルカリ骨材反応は, 現在のところ，アルカリ・シ リカ反応, アルカリ炭酸塩反 応, アルカリ・シリケート反 応の 3 つに分類されておりま すが，アルカリ炭酸塩反応は 対象となる岩石 (鈗物) が限 定されておりますし，アルカ リ・シリケート反応は発生し た地域が限定されております ので, 普通, アルカリ骨材反 コンクリート工学 
応と言われているものはアルカリ・シリカ反応を指すこ とが多いわけです。

[小林］いま内川さんから，アルカリ骨材反応には 3 つのものがあるというふらな括がありましたが，現在 日本で起きてるようなもの, 問題になってるものは, 主 としてアルカリ・シリカ反応ですね。

[内川 はい，そのように考㝋てょいかと思いま す。日本でひびわれの発生, 剝離, 劣化などの現象が見 られるコンクリートのうち，アルカリ骨材反応がその原 因であると確認されたものはごく一部分なのですが，そ の中では，ほとんどがアルカリ・シリカ反応によるもの でございます。

[小林］そういうことで，本日はアルカリ骨材反応の らち，アルカリ・シリカ反応を中心に取り上げたいと思 いますが，いちいちアルカリ・シリカ反応と言うのも厄 介ですから，アルカリ骨材反応と言えばアルカリ・シリ カ反応を指すといらことにしたいと思います。

アルカリ骨材反応による劣化は, この 7,8 年来, 世 界的に増大する傾向にあるようです。

イギリスでは 1976 年以後, 各地で発見されておりま すし，また，西ドイツでも劣化事例が報告されておりま す。

「“Concrete Science”」といら本に載っている 1940 年 から約 35 年間に発表されたアルカリ骨材反応に関する 世界中の研究報告の数の変化を示した図を見ると，1950 年ごろをピークにして減少し始めた論文の数が, 60 年代 に入って再び増え始めているわけです。これは，とりも なおさず，アルカリ骨材反応による劣化事例が世界的に 増大し始めているというふうなことを意味すると思いま す。

\section{- アルカリ骨材反応の原因}

[小林］この原因につきましては, 一般に, セメント 中のアルカリ分が増えてきたとか，あるいは骨材資源が 枯渴してきたんで未経験の骨材とか海砂を使用するよう になったとか, 施工不良によるコンクリート品質の低下 といらふうなことが指摘されているわけです。そのほ か, セメント量の多い高強度コンクリートの使用という こともあるようですが，まずセメント中のアルカリ分が 増えてきたということについて，それぞれご意見があろ うかと思いますが，どうでしょうか。

[嵩］ご専門の内川さんから打話しいただいたほうが いいと思いますが，昨年末，セメント協会から，わが国 のセメントのアルカリ分の推移について, “セメント中 のアルカリは増えていない”といらふらな資料が出され たわけですが，これを見ますと，平均的には変わってい なくても, ばらっきが大きくなっているとすると, アル
カリ量が “増えている”ことと同じとみなさざるを得な いだろうと思います。そういう意味から言うと，いまの セメントの製法上の問題はいかがでしょらか。

[小林］いろいろ物の本によりますと, 近年になって セメントの製造方法が湿式から乾式に変わってきた。熱 経済のために SP キルンによる焼成方式に変わってきた が, これに伴って，全般的にはアルカリ分が増える傾向 にあるんだと言われておりますが，内川さんのほうから ひとつその辺について…...

[内川 この問題につきましては, セメントの中のア ルカリがどこからくるのかということをご説明申し上げ たいと思います。

セメントの原料の一つであります粘土の中に, アルカ リを含む正長石 $\left[\mathrm{K}\left(\mathrm{AlSi}_{3} \mathrm{O}_{8}\right)\right]$, 曹長石 $\left[\mathrm{Na}\left(\mathrm{AlSi}_{3} \mathrm{O}_{8}\right)\right]$ といら鉱物があります。このアルカリは，セメントの焼 成工程で一部は揮発してなくなりますが，一部はセメン トクリンカー中に残るわけです。

粘土は, セメントの中のアルミナ分とかシリカ分を一 定值にするために欠かせない原料でありますので，必然 的にセメント中には少量のアルカリ，つまりナトリウム とカリウムが含まれるわけですが, 石灰石, 珪石, 鉄原 料, 石こうなどの粘土以外の原料はアルカリをほとんど 含みませんから，粘土が一番の原因と言えます。

したがって，セメント中のアルカリ量はどういった種 類の粘土を使うかによって決まってしまうわけですね。 アルカリ含有量が少ない粘土を原料に使えば，セメント の中のアルカリも少なくなり，多いものを使えば当然多 くなるわけです。

日本のセメント生産量は, 私が就職しました昭和 31 年ごろでは，お拉よそ 1000 万トン位であったと記憶し ております。ところが現在では約 8000 万トン， 4 年位 前の最も多く生産したときには，約 9000 万トンですか ら, 過去約 30 年足らずの間に約 10 倍, 1 けた上の量に 達したことになります。したがいまして，原料として使 用する粘土量も，それに応じて増え続けてきたわけです が, 当然の結果として, 風化のよく進んだアルカリ含有 量の少ない易焼性の良質の粘土は枯渇しつつあります。 このような事情から, セメント用としては最適でなくて も，許容し得る範囲であれば，そのような粘土も使わざ るを得なくなりつつあります。したがって，何も対策を 立てないでいると，アルカリが増える方向にゆくという 可能性は潜在的にあるわけです。

[小林］そらしますと，製造方式の影響もあります が，どちらかというと原料の粘土の影響のほうが卓越し ていると…..

[内川 良質の粘土の分布は地域的に偏っており，そ のような粘土が比較的容易に入手できる地方にある工場 


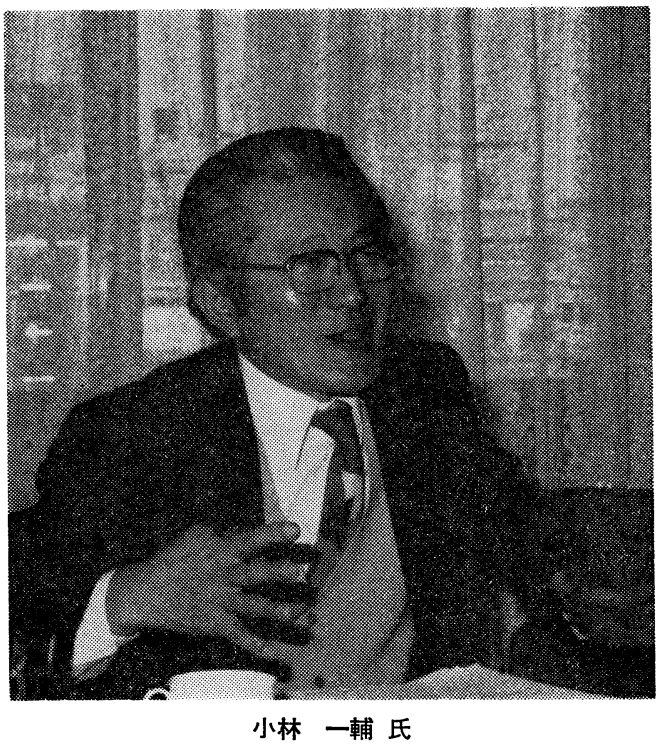

では, 現在でもアルカリが少ないセメントを生産してい ます。また, プッシャーバージ方式とか, 特別の輸送手 段を開発して遠隔地から良質の粘土を運んでくるとか， 新しい粘土質原料を探索調查するなど，セメントの価格 と製造コストの関係で許されるぎりぎりの線までの企業 努力を行っている，といらのが現状ではないかと思いま す。

[小林] イギリスの Cement \& Concrete Association の Palmer さんも，やはり “製造方式の問題よりも原料 の粘土の影響のほうが大きい”といら見解を持っておら れるようですが，そういうことになりますと，やはり工 場ごとにアルカリ分の差があるということも言えるわけ ですね。

[内川 ええそそれはそう言って間違いないと思いま す。使用粘土は当然違いますので.......

[小林］アルカリ骨材反応といらことで, いま一つの 相手のセメントのほうの話をしたわけですが，もう一つ の要因として, 骨材があると思います。

骨材資源の枯渴に伴って, 砕石の使用が砂利上りも増 えてきたとか, 海砂の問題, その辺について，嵩さんか ら少し現状を……

[嵩］アルカリ・シリカ反応といらのは，われわれと しても寝耳に水で, 教科書で習った範囲では日本には起 こらないといらことで安心しきっていた面がありまし た。数年前から, 関西ほかの地域でアルカリ骨材反応の ような現象がありそうだといら話が聞こえてきたわけで す。

それまで私ども建築のコンクリート技術者の関心は海 砂のほうにあって，その一環として骨材調査もやってお りましたが, 粗骨材のほうは, 特に関西以西については
問題はないと考えておりました。最近かなり広範囲な骨 材調査を行いましたが，阪神地方の実際の被害と照らし 合わせて，ある特定の骨材，特にクリストバライトの含 有量の多い骨材が原因であろらといら観点から，いろん な試験方法で調査をしております。非常に安全率を高く する，つまり怪しいものを全部排除するといら形をとる と，おそらく阪神地区の骨材の 8 割ぐらいは怪しいとい う言い方になるのでしょう。厳しく限定すると，これは 確実に危険な骨材だというのは少ないというょうに思い ます。

40 年代後半ごろからこのような現象が起こってきた 背景には, 日本の骨材事情の推移といらことがあると思 います。大体 40 年代前半までは，全国的にはほとんど 名目的には川砂利でまかなわれていたのが，40年代後半 から急激に砕石の使用が増えて，現在では $50 \%$ を超し ているといら状況にあります。

ただ最近，実績の少ない砕石工場というのが，どんど ん各地で増えております。ダムとか原子力発電所などで 新たに砕石を開拓するときのような十分な骨材試験をや らないで，砕石工場が開かれるといらこともありますの で，この辺に問題があると思います。

[小林］海砂につきましては，また後で出てまいりま すが， 3 番目に，いわゆる施工不良一一不良というとち よっと語弊がありますが, この問題についても最近, 土 木構造物の中性化の速度が非常に早くなっているという ことが言われておりまして，無視できない要因じゃない かと思います。

コンクリート構造物の施工といらことになると，やは り嵩さんのほうから一言何かあるべきだと思いますが。

[嵩］私は，個人的にはアルカリ骨材反応と施工不良 というのは直接の対応はないと思っています。

[小林］施工といらのは全般的な問題で，アルカリ骨 材反応だけではなくて鋼材腐食とも関係がありますが, 施工はコンクリートの品質, 寸なわち透水性, 透気性を 左右しますので, アルカリ骨材反応とも関係があるとい ら意味でいま申し上げたわけです。

[嵩］海砂とか，中性化による耐久性の低下といらこ とに関しては, 施工の良否が大きな要因を占めるだろう と思います。言い換えれば，一般的な耐久性の問題につ いては, 施工のレベルを上げることによってかなり改善 の余地はあります。

しかし、アルカリ骨材反応は本質的に施工の程度と無 関倸に発生し，どんなに良い施工をした構造物であって も発生する現象です。もち万ん，ひびわれとかじゃんか などから雨水が渗透してアルカリ・シリカ反応を促進 するといら意味では，施工の良否は関係しますけれども …. 


\section{- 骨材の反応過程}

[小林］この辺で, アルカリ骨材反応によってコンク リートに劣化が生ずる条件と申しましょうか, この辺に ついてお話を伺いたいと思いますが，単純に考えると， 使用骨材の全量が反応性の骨材の場合に最もひどい劣化 を生ずるようにわれわれ思らんですが，現実にはそらで はなくて, 健全な骨材中の何％かが反応性骨材の場合 に最悪の状態になるといらふらに言われております。

量的なバランスと言いましょらか, そらいうものはど らでしょうか。骨材の反応面積の関係であるとか.......

[内川）いま小林先生がご指摘になったのは, アルカ リ骨材反応特有のペシマム現象のことだと思います。ご 指摘のとおり, ペシマム効果には, アルカリシリカゲル の組成と生成量と両方が効いています。アルカリ珪酸塩 というのは非常に複雑な性質をもっておりまして, その 特異性がペシマム効果をもたらすわけです。

それから，ペシマムが出る要因はほかにいくつかあり まして，たとえばコンクリートの水セメント比にもペシ マムがあるわけです。

水セメント比が大きくなりますと, 硬化コンクリート の空隚が当然多くなり,アルカリシリカゲルによる膨張 が空隚に吸収されてしまい, 応力が伝わりにくくなりま す。空隚率が大きくなりますと, 空幥溶液のアルカリ濃 度が薄くなります。

一方, 水セメント比が大きくなると, コンクリートの 強度が下がります。つまり, 水セメント比を大きくする と, 膨張を起こすアルカリシリカゲルの生成が少なくな り, 膨張が応力となりにくいという条件と, コンクリー 卜の強度が低いために, わずかな応力で破壊されるとい う相反する条件をつくることになり，これらの条件のバ ランスの上に, アルカリ・シリカ反応によるコンクリー トの劣化という現象が乗っているといらことです。言い 換えれば, 劣化が一番起きやすい水セメント比があると いらことで，その值は $60 \%$ 前後と言われています。

それから，骨材の粒径に対してもペシマムがありまし て, ある特定の粒度, たとえば $0.15 \sim 4.75 \mathrm{~mm}$ のよう な粒度の骨材を使った場合に非常に起きやすいと言わ礼 ています。また, 環境についても, $40^{\circ} \mathrm{C}$ 前後で最も起 きやすいといらデータがあります。これらは，いずれも ゲルの生成量との関連で生じたものと考えられておりま す。

ASTM C 227 「セメントー骨材の組合せによる潜在了 ルカリ反応性試験方法(モルタルバー法)」はこのような ペシマムな条件を考慮に入れて作った規格と考えること ができます。

[小林］ 反応速度といらことになりますと, 温度も関
倸があるんでしょうね, 当然。

[内川，反応速度では, 温度が高くなると速くなりま すから，アルカリ骨材反応が開始する時間が早まり, コ ンクリートの劣化が早く現れると思います。もちろん, コンクリートの強度の発現も促進されますから, それと の兼悋合いであると思いますが……また，その温度で 安定に存在し得る生成物といらのは決まっておりますか ら，アルカリシリカゲルの組成にも影響する可能性はあ ります。

[嵩］先ほどの骨材についての話と，いまの内川さん のお話と総合しますと，水セメント比も関係する話です が，ここ数年来の全国的な生コンの水セメント比の傾向 から言いますと, 平均的には $57.8 \%$ ですが, 砕石の場 合には $60 \%$ 前後という水セメント比が一番多い。この 辺のところが, バックグラウンドとして急に 50 年前後 から出てくるということに結びっくと思いますが，いか がでしょうか。

[内川 理屈からいきますと, 川砂利, 川砂であって も, 砕石であっても, アルカリ・シリカ反応を起こすよ うな鉱物を含んでおり，コンクリート中に十分な湿度と アルカリと反応性シリカが含まれるといら条件が満たさ れれば, アルカリ・シリカ反応は起こります。

[嵩] それと, 砕石の原石は, 昔は砂岩, 石灰岩など の系統が多かったのが, 最近は安山岩系が増えておりま すね。

[内川］骨材の物理的性質といら面から考えますと， 安山岩系統のものは非常にいいものです。アルカリ・シ リカ反応の危険性があるような鉱物を含んでいない限り は，コンクリート用の骨材としては非常にいいものだと いらふうに考えられます。

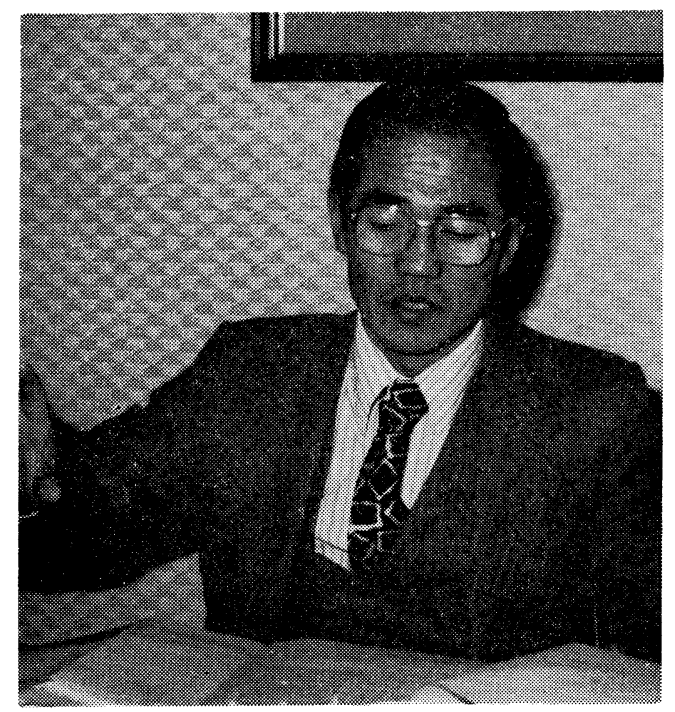

内川浩 氏 
また, 地殻全体に占める安山岩の割合は非常に高いわ けですから, 自然の成り行きとして, その使用の割合が 多くなったのではないでしょらか。

\section{- 外観変状亡強度}

[小林］やは構造物が置かれる条件によって, 劣化 の出方がいろいろ違うと思うんですが，ここで，アルカ リ骨材反応によって劣化を生じたコンクリート構造物の 外観について取り上げたいと思います。これは一般にマ ップ状ひびわれと言われておりますが，無筋コンクリー 卜構造物の場合と鉄筋コンクリートの場合とでは違いま すし, 同じ無筋コンクリート構造物でも, いわゆるスラ ブのような広がりをもったものと, 海岸堤防のような細 長いものでは, また出てくる形が違うと思いますが, こ の辺について嵩さん, いままでいろいろ調査をされてき たところを解説していただけますか。

[嵩］アルカリ・シリカ反応によるコンクリート構造 物の被害は, ひびわれとポップアウトと変形の 3 つの現 象に大きく分けられます。

ひびわれは, 膨張現象特有のマップひびわれと呼ばれ る，3方向に枝分かれする網目状のひびわれを生ずる場 合と, 拘束の小さい方向に直角のひびわれを生ずる場合 とがあります。網目状のひびわれについては, 昨年のテ レビで放映されたような鉛筆が入るようなひびわれ幅の ものから, 微細ひびわれのような非常に小さい幅のもの まで, 先ほどのいろいろな条件の組合せで変わってきま す。網目状のひびわれでご注意いただきたいのは, コン クリートの表面にモルタル仕上げが施されている場合, モルタルの収縮ひびわれとの区別は，外観だけでは困難 だといらことです。モルタルのひびわれは，コンクリー トの膨張とモルタルの収縮のいずれの原因でも同じパタ ーンで発生します。したがって, 仕上げのある建物の外 壁のひびわれについては, 現在, アルカリ骨材反応の疑 いをかけられているもののうちには, 単なるモルタルの 収縮ひびわれもかなりあると思います。従来, モルタル の収縮ひびわれとして片付けられていたもののうちに も, アルカリ骨材反応によるものもあるかも知れません が……

ひびわれのもら一つのパターンである, 拘束の小さい 方向への直角のひびわれというのは, 横方向に長い壁, 擢壁, 高架橋の橋脚のはり部分などでは水平方向に出ま すし，柱部分などのように鉛直方向の拘束を受ける部材 では鉛直ひびわれとなります。

ポップアウトといらのは, コンクリートの表面に円錐 状のクレーターを形成するような㓦離を生ずる現象で す。ポップアウトは, アルカリ炭酸塩反応と違って, ア ルカリ・シリカ反応の場合には必ず発生するとは限りま
せん。特に最近, 関西地方で問題になっているような輝 石安山岩の場合には, ポップアウトを伴わない場合が多 いようです。

3 番目の変形というのは, 壁, 擁壁, 高欄, 手すりな どに, そり, 湾曲, 位置のずれ等の大きな変位を生ずる ものです。

アルカリ・シリカ反応によるコンクリート構造物の構 造上の被害というのは, 大体以上の 3 つの現象が, 単独 あるい複合して発生することによるものです。ただ, このような現象を生じても, 必ずしも部材としての耐力 の低下に結びっくわけではなく, 構造的に危険だという ことは意味しません。

したがって, 構造物としての被害としては, 構造的に はひびわれというものが大きな意味をもちますけれど も, 建築物としては, 美観と機能上からポップアウトと か変形も重要だろらと思います。

[小林］鉄筋コンクリートの場合だと,ひびわれは主 鉄筋に平行に出てきます。膨張が鉄筋によって拘束され ますから斌。そういうことで, 無筋の場合とはだいぶ違 う。それで, 大きなひびわれの周辺に，またいまの，い わゆるマップ状の細かいひびわれが少しずつ発展してい くんですね。

ところで, コンクリート構造物がアルカリ骨材反忘に よって劣化した場合, 力学的な性状の変化と申しましょ うか,はたして強度がどのくらい減っているのか,そうい う面でのデータがあまりないんじゃないかと思います。 訔さんのほうでは，いろいろお調べになっていることと 思らんですが.......

[嵩] ごくわずかな調査例しかありませんが，アルカ リ骨枋反応の生じている構造物について, コア供試体の 試験と, 部材の曲げ載荷試験を行った例について申し上 げます。

材令は約 10 年で, 現象としては壁体の湾曲, ずれと 水平方向のひびわれと網状ひびわれを生じており, 電子 顕微鏡によるアルカリ骨材反応状況，X線回折による鉱 物組成と反応生成物の確認などから，アルカリ・シリカ 反応であることが確認されています。

コア供試体による試験では, 圧縮強度は設計基準強度 を十分満たしており，同じ時期に打設した健全なコンク リートと比較しても差はありません。圧縮強度と引張強 度の関係も健全な普通コンクリートと同様ですので, ア ルカリ・シリカ反応を生じても強度の低下は少ないと言 えそうです。ただヤング率は，健全なコンクリートの約 半分に低下しておりました。

[小林］それは, ひびわれがなくても，そのように弾 性係数が下がる場合があり得ますか。

[嵩]ややり，外観上の被害の大小によって差があり 


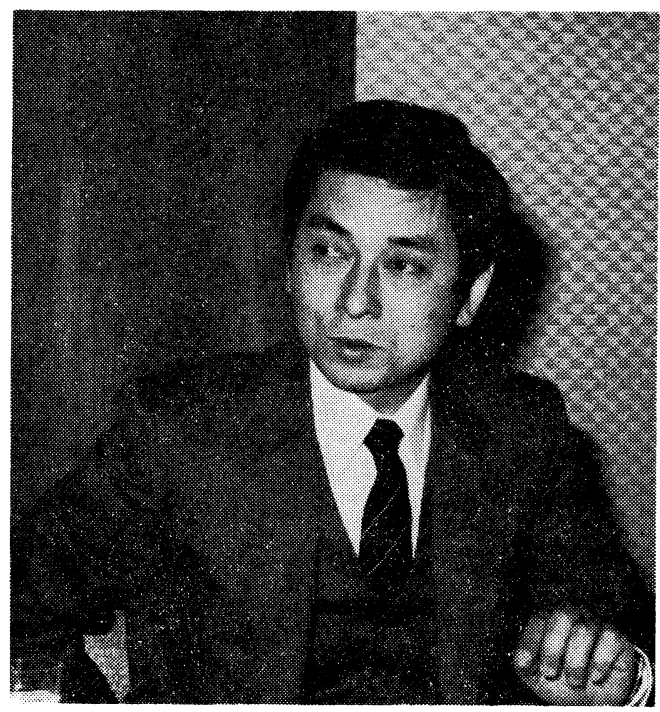

嵩英雄 氏

ますが，表面のひびわれの影響だけとは言いきれない。 骨材周辺の反応リングや微細ひびわれによる影響もある かと思いますけれども……とれと，中性化が若干早い 部材としての耐力ですが, 版の曲げ試験の範囲では耐力 の低下はない。ただ弾性係数の低下と初期剛性は低下す る傾向があります。

[小林］ただ放っておきゃ壊れてくるわけですね，反 态が進行すれば……

[嵩］ それは, 部材の置かれてる環境あるいは内部で の生成の状況によると思います。

[小林］これは後の「対策」のほうに関係があります ので，またそのときお話しいただきたいと思います。

\section{- 類似の現象}

[小林］ いま嵩さんから，アルカリ骨材反応に起因す るひびわれが乾燥収縮のひびわれに似ているというケー スもあるんだといら打話がありましたが，これがはたし てアルカリ・シリカ反応によるものかどらか判定するた めには，普通，コアをとって，骨材に反応リムがあるか とか，あるいは溶出物を調べるとかいうことになると思 いますが，その辺，内川さん何か…....

[内川）アルカリ骨材反応であるか，そうでないのか ということを判定するには，いま小林先生おっしゃった ような方法が一番一般的でございますね。

やはり，何といってをコアを抜きまして，骨材の周辺 に反忘リムが出ているか，その反応リムがプラスの方向 に出ているかマイナスの方向に出ているかというょうな ことを調べるとか，反応りムの組成を調べてみます。ア ルカリシリカゲルは, 吸水量により, ゲルから変形可能 なゲルになりまして，それからゾルに変わり，それとと
もに流動性も大きく変化します。コンクリートにひびわ れなどがありますと，生成したアルカリシリカゲルは裂 け目を伝って表面に浸出してきますので，それを目視観 察するとか, 分析してみれば分かります。

それから，ここで一つ申しげておきたいのは，コン クリートにひびわれが発生したり，ポップアウトが生じ たりして劣化した場合，その原因を調べてみますと，ア ルカリ骨材反応によるものではなくて，自然環境下で骨 材自身が変質・膨張したことが原因である場合が非常に たくさんあるという事実です。

2,3 例を挙げますと，マグネシウムを含む骨材を用い ますと, 炭酸化, 水酸化を受け, コーリンガイトとか含 鉄ブルーサイトのような含水の塩基性炭酸鉄マグネシウ ム, あるいは水酸化鉄マグネシウムなどを生成し, アル カリの存在とは無関係に膨張します。

また，濁沸石（ローモンタイト $\mathrm{CaO} \cdot \mathrm{Al}_{2} \mathrm{O}_{3} \cdot 4 \mathrm{SiO}_{2}$. $\left.\mathrm{H}_{2} \mathrm{O}\right)$ という鉣物がありますが，これが骨材の中にある と, 乾湿の繰返しにより膨張収縮を繰り返し，コンクリ ートを劣化させます。

層状構造をもっている粘土鉱物も，環境の湿度の変化 に応じて膨張収縮し，このようなものを含む骨材を用い た場合にもコンクリートは劣化します。

[小林］アルカリ骨材反応ばかりにとらわれているが， ほかにもいろいろあるといらことだと思いますが…....

[内川] もう一つ，わりあい日本でよく起こっている 例としましては，黄鉄鉱，白鉄鉱，磁硫鉄釷のような硫 化鉄鈗物が骨材の中に含まれていますとこれが酸素と水 の存在下でセメント中のアルミナ分と反応し，エトリン ガイトを生成して膨張するとか，骨材中に硫酸塩鉣物が 存在した場合に，やはり，エトリンガイトを生成して膨 張し，コンクリートを劣化させた等の実例があります。 したがって，コンクリートが劣化した場合には，アルカ リ骨材反応によるものか，それ以外の骨材が環境条件下 で変質・膨張した結果によるものか，きちっと区別して 対処することが大切じゃないかと思います。

[小林］ただ非常に残念なことに，いま内川さんのお っしゃったローモンタイトとか，いわゆるそういうアル カリ骨材反応以外のものについては, 日本でも事例がす でにいくつか起こっているはずなんですが，そういうも のは表に出ないんですね。おそらくこらいう骨材の反応 でこのよらにオープンに出てきたのは，どうもアルカ リ骨材反応が初めてのように思いますね。そういった意 味では，いま内川さんのち話しになった，アルカリ骨材 反応以外の，そういら骨材に起因するいろんな劣化につ いても，これからやはり検討していかなければいけない かと思います。 


\section{- 骨材之鉱物}

[小林］次に，どういう骨材がアルカリ骨材反応を起 こすのかといらことで，これにつきましては冒頭に内川 さんのほうから少しご説明をいただいたわけですが，こ の問題については，かなり誤解，混乱があるように思い ます。

たとえば，去年NHKが報道した輝石安山岩犯人説が あります。届いたばかりの「コンクリート工学」誌 2 月 号では, 金沢大学の川村先生が “反応性の鉱物と岩石の 区別をして考えることが大事だ”と指摘しておられます が，私も同感です。そこで，骨材と岩石と反応性鉱物と の関係について話を進めたいと思います。

反応性の鉱物を大きく分けると, シリカ鉣物と火山性 ガラスぐらいのところでしょうか。

[内川 流、シリカ鉱物がその主体です。火山性ガ ラスもシリカを含んでいます。

シリカを含んでいる鉱物は, アルカリ骨材反応を起こ す可能性はありますが，反応速度がきわめて遅いもの は，実質上沛応しないというふらに考えてよいという ことです。具体的に中しますと，玉髄のように鉱物を構 成している結晶の粒度が非常に細かいものとか, 石英の 結晶変態の一つであり, 常温下では準安定であるトリジ マイト, クリストバライト, 結晶度の低いオパール, 潜 晶質石英, 非晶質の火山性の酸性ガラス, 結晶格子がひ ずんだ石英などの鉱物やガラスを含む岩石から製造した 骨材は, アルカリ・シリカ反応を起こす可能性が高いと 申せましょう。

このような鉱物やガラスを含む岩石を挙げていきます と, 安山岩, 石英安山岩, 流紋岩抢よびそれらの凝灰 岩, 玄武岩, 花崗岩, 頁岩, フリント, チャート, 砂岩, 硬質砂岩 (グレイワッケ), 珪岩, 千枚岩, 片岩, 片磨 岩, 泥岩など, 非常に多種類の岩石が該当することにな ってしまいます。

[小林］火山岩とか, いわゆる火山岩質の凝灰岩とか 変成岩, この辺は全部対象になるわけですね。

[内川 ええ，そういうことになるわけで，どの岩石 が危ないというような言い方は, しないほうがいいとい らふらに考えております。

それよりも，どういう鉱物がどの程度含まれているか ということをきちんと押さえて判断することが大切であ ると思います。それから, 岩石中に鉱物が存在する状態 も重要なことです。岩石は, マグマが泠却されて, ある ものはその後変成を受けて出来た天然のものですから， 一般には不均一なものであると考えられます。ある部分 に特定の元素あるいは鉱物が濃縮されて存在するという ようなことも，ごく普通にあります。そういうことをき

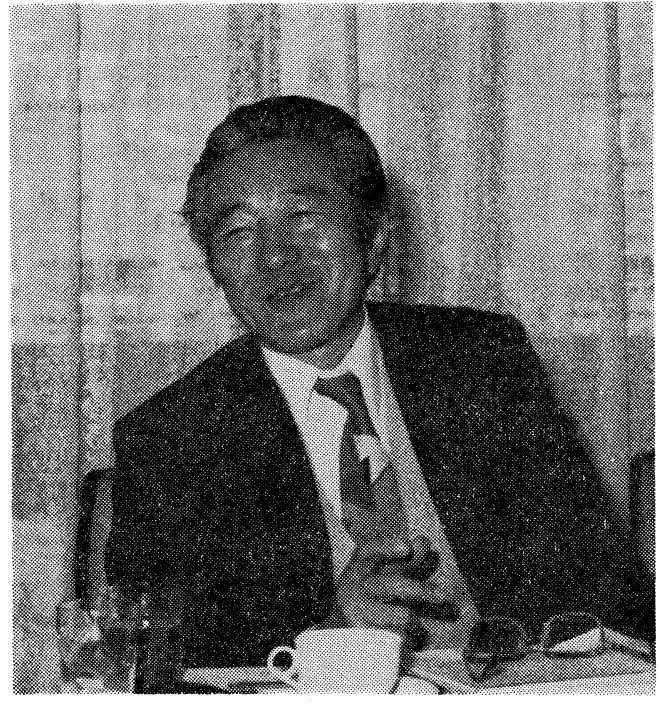

ちっと調べずに，ただ何とか岩は危ないとか，何とか岩 は大丈夫だとかいら言い方をすることは適切でなく，世 の中に誤った印象を与えることになります。

[小林］そうですね。ただ問題は, チェックする方法 に関係することですが，あるところから持ってきた骨材 は全部同じ岩石から出来ているかといらと，これはまた 必ずしもそうとも言えないということで,「反応性の鉱 物を含む岩石を含む骨材」という表現が正しいことにな りますか叔。

[内川） ええそそうらことです。

\section{- 骨材の反応性試験方法}

[小林］これをいかにしてチェックするかという話な んですが，ご存じのように，ASTM にモルタルバー法 あるいは化学法などがあるわけですが, 要するに, これ らの方法の実用性の問題だと思います。その辺について は, 内川さんのところではもちろん, 嵩さんのほうでも おやりになっているようですが，判定試験方法について 少しご議論いただきたいと思います。

モルタルバー法は，やはり時間がかかるということが 一つ欠点としてあるようですが，内川さんのところで は, この二つの方法の使い分けについて, まず化学法で やって, 有害であるといら結果が出たものについて, 今 度はモルタルバー法をといらふうにやっておられるわけ ですか。

[内川～はい。ASTM C 289「骨材の潜在反応性試 験方法 (化学法)」による判定については, 世界各国で 批判があります。この方法による判定の信頼性について は, われわれも疑問を持って招ります。有害な骨材を排 除するといらことよりも, 無害なものを確認する方法と しては使ってよいと思います。化学法で有害, あるいは 
潜在的に有害であるという結論が出たものについては， モルタルバー法による試験をしてチェックしています。

モルタルバー法については, 化学法に比べると, 比較 的批判は少ないのです。今のところ他に適当な方法がな いから，まあ仕方がない，という意味での消極的是認で す。この方法は, 結果を得るまでに時間がかかることと, 6 か月までは膨張しないで， 6 か月以後に急激に膨張す る骨材がかなりあり，そのような骨材に対しては判定を 誤るおそれがあるという点が弱点となっています。

それから ASTM C 245 「コンクリート用骨材の岩石 学的試験方法」という規格があり, 岩石鉱物的な手法を 用いて骨材中に含有される反応性の高い鉱物を検出, 同 定, 定量して骨材の適否判定のための一つの資料として います。

嵩さんのほうで判定試験をやっておられ，何か問題点 があるかと思うんですが.......。たとえばサンプリングの 問題とか…....

[嵩］ サンプリングの問題といらのは, 先ほどの骨材 の衫話のと抢り, 骨材というのは成分あるいは原石の分 布も均一じゃありませんので, かなり広範囲にサンプリ ングせざるを得ない。しかも，サンプリングした骨材を 粉砕する場合でも, その辺の再現性というものを高め る, あるいはこういら鈗物について集めて，さらにそれ らのペシマム現象の起こりそうなところを選ぶとかいう 注意も必要と思います。

もう一つ問題は，何のためにそういう試験をやるかと いう問題だろらと思らんです。完全に白だということを 判定するための試験をするのか, あるいは完全に黒だと いらものを排除するための試験なのか, それといつの時 点でやるかといらのが早期判定や長期の試験と絡むと思 うんです。

たとえば ASTM のモルタルバー法などを, 日常のコ ンクリートのユーザーサイドの品質管理試験に使うとい うことは, 意味をもちません。この方法は, やはり新し く採石の山を開くとか, あるいは骨材の採石の決定のと きに使うべきものです。ですからこれは，ある程度時間 がかかっても，やむを得ないでしょう。

それに対して早期判定といらのは, 大なり小なり非常 に過酷な条件を作り出してありますので, 実際の構造物 では被害を生じないようなものまで，有害だと判定する 危険があるわけです。

[小林］同じサンプルから分けて別々にモルタルバー を作って試験したところ，一方では反応性があり，他方 では反応性なしという結果が出たということも聞いてお りますが，なかなかむずかしいようです。

\section{○ セメント中のアルカリ分とその低減}

[小林］この辺で, セメント中のアルカリ分とその低 減対策というふうな話に移りたいと思いますが，アメリ カでは, 反応性の骨材が出るようなところでは ASTM で $\mathrm{Na}_{2} \mathrm{O}$ 換算で $0.6 \%$ 以下のセメントを使いなさいと いうことになっているようですし, 先ほどから話題にな っているイギリスの C \& CA のガイダンスノート（編 注・本誌 4 月号参照) でも複数の方法が提案されていま す。反応性骨材を使わないといらことはもちろんありま すが，セメント中のアルカリ分が，やはり $0.6 \%$ 以下の ものを使うとか, あるいは高炉スラグやフライアッシュ のような混和材を使うとか, あるいはコンクリート中の アルカリ分を $3 \mathrm{~kg} / \mathrm{m}^{3}$ 以下に制限するといらふうな措置 を，一応これはまだ暫定的なものだと断ってはおります が，提案しているわけです。この辺について，まず内川 さんのほうから打願いします。これは, 最終的に日本で どうやれとかいう話ではないんですが，私はイギリスの やり方というのは，非常に現実的な対応のように思って いるわけです。

[内川］アルカリ骨材反応を防ぐための一つの方法 は，コンクリート中のアルカリ量を減らすことが考えら れます。その対策として，現実にすぐできるかできない かは別問題として, セメント中のアルカリ量を減らす か, 元々アルカリ含有量が少ないセメントを使用すると いうことも一つの方策でしょう。

たとえば耐硫酸塩セメントといらのがありますが，こ れは地中あるいは流水等のながある硫酸塩に対して抵 抗性を上げるために，七メント中のアルミン酸カルシウ ムの量と, 珪酸カルシウムの中でエーライトの割合を減 らしてビーライトの割合を多くしたものです。

このようなセメントを製造するためには, 珪石の使用 原石単位を増やし, 粘土の使用割合を減らせますので, 必然的にアルカリ量は低くなります。日本の例で申しま すと, 耐硫酸塩セメント中のアルカリ量は, $\mathrm{Na}_{2} \mathrm{O}$ 換算 で 0.5 0.6\% の水準にあります。

アルカリ・シリカ反応を起すおそれのある骨材をやむ を得ず使用する場合には，耐硫酸塩セメントを使えば， アルカリ・シリカ反応によるコンクリートの劣化を防止 するとができるということになります。

[小林] イギリスの例でも, 要するにイギリスの中で は，0.6\% 以下のセメントは現実に入手できないんだか ら，その場合に注，耐硫酸塩ポルトランドセメントを使 いなさいといらようなことが，たしか書いてあったかと 思いますが…...

[内川そそういうことでございまして，外国でもそう いらリコメンドを用いております。 


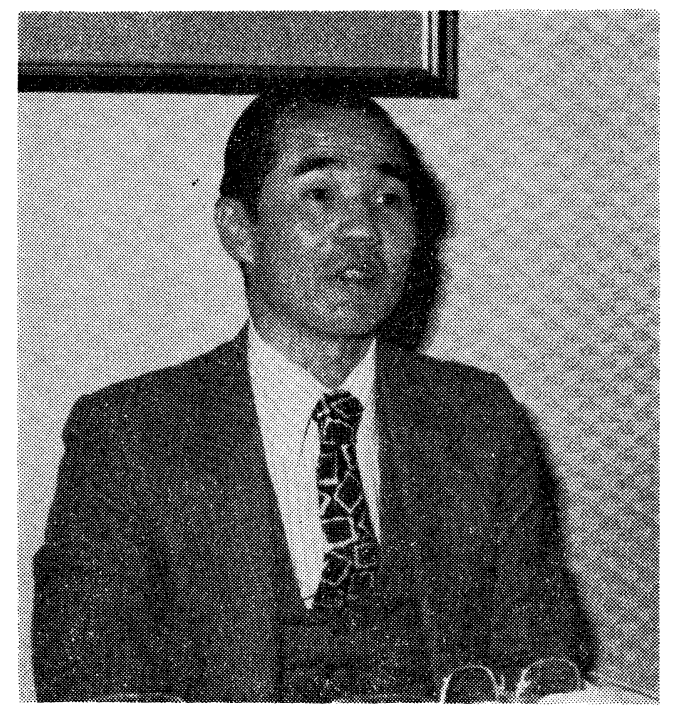

精選した原料を使用すれば，アルカリ含有量が現在の レベルより低い普通ポルトランドセメントを製造するこ とは技術的には可能であり，現に南アフリカでは，セメ ントメーカーが使用原料を厳選してセメント中のアルカ リ量を $\mathrm{Na}_{2} \mathrm{O}$ 換算で $0.8 \%$ に自主規制しようといら試 みがなされています。これは現実的な新しい動きの一つ と思いますが, わが国では, 諸般の事情を考えますと, ユーザーが希望されているよらな值段で提供できないの ではないかと危惧しております。

[小林］耐硫酸塩ポルトランドセメントは, 耐塩性と 言いましょうか，塩素イオンがたくさん入ってくるよう な海岸構造物とか，ああいうところに注，どうもあまり 適切ではないように思います。中の鋼材腐食との関連 で，そのように考えているわけですが…...

もう一つは，2 番目に申し上げた高炉スラグあるいは フライアッシュの使用といらふうなことがあって，たし か内川さんのほうでその有効性について研究をしておら れると思いますが……

[内川］フライアッシュ, 高炉スラグの使用は, 各国 の粯格，あるいは指針にすでに取り大れられておりまし て，反応性の高い骨材をやむをえず使用する場合には， イギリスでは，高炉スラグを少なくとも50\% 含むセメ ントを使用する，フライアッシニを少なくとも $25 \%$ 混 合したセメントを使用し, コンクリート中のアルカリ量 を $3.0 \mathrm{~kg} / \mathrm{m}^{3}$ 以下にすること交すするて招り，南アフリ カでは，高炉スラグ $50 \%$ 以上，フライアッシュ $20 \%$ 以上の混合を，またアメリカでは，フライアッシュおよ び高炉スラグを添加するよう指導しています。西ドイッ では, 普通セメント中のアルカリ量が $\mathrm{Na}_{2} \mathrm{O}$ 換算で 1.1 \%の場合，高炉スラグ $50 \% ， 2 \%$ の場合 $65 \%$ 混合する ことを規格化しようとしています。

\section{○アルカリ骨材反応の促進要因}

[小林］次に，アルカリ骨材反応を促進させている要 因なんですが，先ほどの海砂のほかに塩化カルシウムも 促進させるし，防錆剤もそのおそれがある。最近関西で 発生しているアルカリ骨材反応の被害例を見ますと, 大 体海砂や塩カルを使っているケースが多いようですね。

もう一つ, 先ほど施工の問題を持ち出しましたけれど も, これらが組み合わさって, いわゆる複合要因で特に 関西に集中的に出てきたといらふうな感じがするんです が, 嵩さん, いろいろ調べておられてどらでしょうか。

[嵩] 海砂は, ちょうど 40 年代の終りごろというの は,一種の野放しに近い状態だったわけです。ですから， あのころの構造物というのは, アルカリ骨材反応以外に も，かぶりの不足と合わせて，鉄筋のさびといら被害が 比較的多い時期です。

その後, オイルショック以後, 特に JCI の海砂塩分 濃度の規制值の提案等がありまして, 現在ではかなり改 善されています。現在, 細骨材で測った例では, 主要な 生コン工場での調查では, 海砂中の塩分濃度は大体 0.03 \% 程度という非常にいいデータが得られておりますの で, 最近の構造物については, 塩分といら意味では, 大 阪近辺では安心していいと思うんです。そういう意味で は, やはり 50 年前後というのが条件としては一番悪か った時期かなと思います。

現在では, 関西以西, 海砂使用地域では, ほとんどの 生コン工場ではノン塩カルタイプの減水剤を使っており ますので, 促進要因は, かなり排除されていると思いま す。

[小林] も5一つ, 最近, 高性能減水剤が出来て, か なり単位セメント量の大きいコンクリートが使われるよ らになった。これは，建築のほうはどらか分かりません が，土木のほうは，プレストレストコンクリートのよう に高強度のコンクリートの使用が増加し, 結果的には, 全般的にセメントの使用量が増えている。この辺もアル カリ骨材反応の促進要因の一つということになると思う んですが.......

[嵩] 建築物については, 関西以西の海砂使用地域に ついては, 水セメント比 $55 \%$ 以下といら建設省の通達 がありまして, それを守りますと, コンクリートの呼び 強度に直すと $240 \mathrm{~kg} / \mathrm{cm}^{2}$ 以上の高い強度のコンクリー トを造ることになりますので, そういう傾向は, 特に関 西以西では強いと思います。

ただ, 高性能減水剤がセメント量を増やしているとい らのは，建築については逆だろうと思います。むしろ， 同じ強度であれば，セメント量を $10 \%$ 程度まで減らす といら使い方が一般的に採用されています。

コンクリートエ学 
[小林］流動化剤的に使えば減るわけですね。

しかし，水セメント比を小さくするために使えば増え てくるということになるわけですね。

[嵩］建築での使い方については，ほとんどが同じ強 度で, 低スランプのベースコンクリートを流動化すると いら形で, セメント量を減らす使い方になっていると思 います。

[小林］それでは，この度のアルカリ骨材反応の問題 をめぐる内外の動きのほうの話に入りたいと思いますが

[嵩］その前にもう一つ, アルカリ骨材反応の被害を 助長する要因として, 仕上げの問題があると思います。 土木構造物とは違って, 建築構造物は仕上げが施され ている。特に 30 年代から 40 年代前半ぐらいの構造物 というのは, タイルのような比較的へビーな仕上げのも のが多いわけです。ところが，40 年代後半ぐらいから 比較的仕上げが軽微な構造物が増えていますので, その 辺が，いまの骨材の要因あるいはセメントの要因と合わ せて, 建築で被害が出る要因となっているケースはあり 得るかと思います。

[小林］土木構造物は裸ですから㱛。その辺, 条件 はよりはっきりしますね。

\section{- 学協会の対応}

[小林］今回のアルカリ骨材反応問題では, 日本コン クリート工学協会 (JCI) に, 岸谷先生を中心とする対策 委員会が発足しようとしております。

これは, 土木, 建築両学会をはじめとする関連学協 会, 専門家, 大学, 官公庁までのメンバーから構成され る総合的なものでございまして, 向こう 3 年間を目途と してアルカリ骨材反応に関するガイドラインを作成する といらことを目標にしたものですけども, この問題に関 する海外諸国の最近の対応一イギリスについてはC \& CA のガイダンスノートの話が出ておりますが—につ いて, 内川さんからお話を伺いたいと思います。内川さ んはセメント協会の対策委員会の主査として, いろいろ 調査をしておられるというららに聞いておりますが…...

[内川 セメント協会の中に, セメント化学専門委員 会という常置の委員会がございまして, そこでアルカリ 骨材反応に関する調查・検討を約 1 年前から開始してお ります。

その一環として先進諸国におけるアルカリ骨材反応に 対する取組みや規制の実態など, いろいろ聞いてみよう じゃないかといらことになりまして, アンケート形式に よる簡単な質問状を送りまして, イギリス, 南アフリ カ, 西ドイッ, アメリカ, ブラジルから返事をもらいま した。
返事の全体を通しての傾向としては, アルカリ骨材反 応は，これら各国においても大きな問題となっており， 大体において先ほど述べたような対策を取っておりま す。大部分の国では, セメント中のアルカリ量の規制を 強化しようとは考えておらず，骨材の選択基準について は，ある国とない国とがあるものの，コンクリート用一 般骨材の試験方法とアルカリ骨材反応に対する対策と併 用すれば，相当程度までアルカリ骨材反応によるコンク リートの劣化を未然に防止することができると考えてい るようです。これらについては，今年の 5 月に刊行され る予定の, セメント協会セメント化学專門委員会報告 C-2「アルカリ骨材反応に関する文献調查」に記載され ておりますので, 詳しくはそちらをご参照いただきたい と思います。

[小林］いま，諸外国ではどう考えているかといら点 についてご紹介いただいたわけですが，例のイギリスの C \& CA のガイダンスノートを見ましても，これはイ ギリス内における適用のみを考えていると断っておりま す。この問題がいかにむずかしい問題があるかといらこ とを示しているよらに思います。

日本における対策については, 先ほど申し上げました JCI の対策委員会が打ち出す対策に期待をしたいと思い ます。

\section{- 補修}

[小林］いままでの話は，どちらかというと，これか ら新しく造る構造物を対象とした対策ということなんで すが，すでに出来上がってしまったコンクリート構造物 にアルカリ骨材反応による劣化が出てきたといら場合の 対策はどうでしょうか。有効な防止対策があるのかとい らことなんですが……。

一つは，外部からの水の侵入を完全に遮断するのがよ いということで, たとえば樹脂系の材料で構造物をシー ルするということが，まず考えられるわけです。しかし それで止まるのかどらかといら話ですが，嵩さん，いか がでしょらか。

[嵩］先ほどお話ししました，実際に被害が生じた構 造物の試験体の断片を切り出しまして何通りかの試験を した結果では，気中ではほとんど膨張しないのですが， それが乾湿の繰返しをやりますと, その数十倍む膨張し ます。これは, 水中における膨張量とあまり変わりませ h。

その場合でも, 防水処理しないものとしたものではか なり違いがありまして, 防水処理したものの膨張量は非 常に少なくなります。水中でも, 防水処理しないものは $0.15 \%$ ほど膨張しているんですが，防水処理したもの は，それが $0.02 \%$ ほどになりますから，とりあえずの 
対策としては, 何らかの防水性の被膜を上につけて水を 遮断してやるというのが一番有効な方法ではなかろうか と考えております。

[小林］それは供試体ですか。

[嵩] 構造物の一部から切り取った試験体で, かなり 膨張, 反応が進行したものです。

[小林］確かにいまのお話は，水を完全に遮断できる かどうか, ということですが, 実際の構造物を完全にシ ールするということは非常にむずかしいということで, その辺はまた, 今後の検討課題なんじゃないかと思いま す。

[内川］確かに嵩さんのおっしゃったのは一つの方法 なんですが，それで完全に反応の進行が停止するという ことにはなりません。外部からの水の侵入を遮断すると いらことは, 要するにアルカリ・シリカ反応の進行速度 を遅くしたにすぎないと思います。C＆CA のガイダン スノートにも確かそのような記述があったと思いますが $\cdots \cdots$ 。

[嵩] ただ，実際に被害を許容できる範囲内におさめ ることができるなら，アルカリ骨材反応の進行速度を遅 らせることも有効だということになりませんか。

[内川 そういうことでございましょうね。反応速度 を遅らせることにより，アルカリ骨材反応によるコンク リートの被害の発生の時期を延ばし, 被害の進行を遅ら せることができれば，そのうちに建設物の予定寿命に達 するわけで, そらすれば十分目的が達せられたというこ とになります。

[小林］ただ“シールをすれば”と簡単に言うんで すけど，シールをする費用は大変なんですね。

最近私が 2,3 聞いた例では，ある構造物を造った。 それで，供用開始するまでにはある程度時間がかかりま

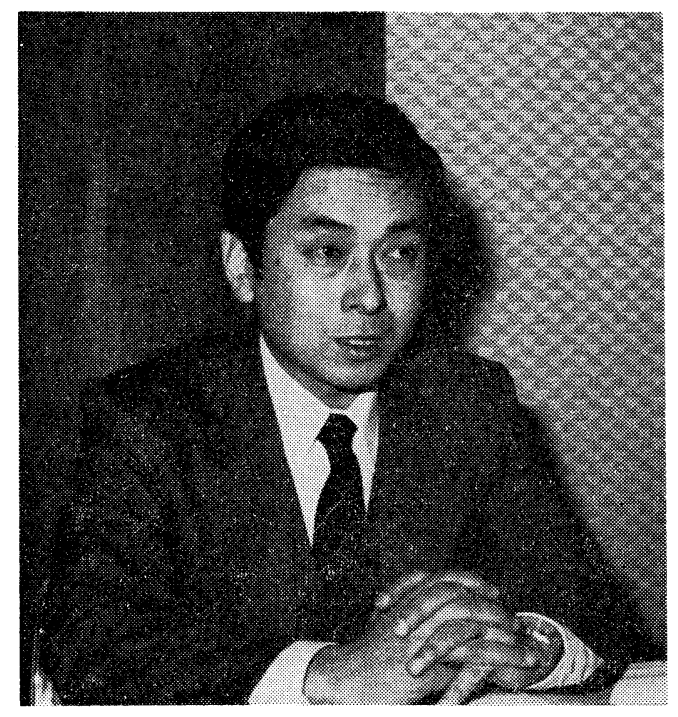

すので，いざ開始しようと思ったらアルカリ骨材反応ぶ 出てきた。そこで発注者は考えるわけですね。シールを して供用するかと。しかし，確実にシールができるとい ら保証がない。あとのメンテナンスを考えると壊してま た造り直した方が利口である。そこで供用開始前に取り 壊して再施工をしたということです。外国の本によると アルカリ骨材反応のことを Cancer of Concrete (コン クリートのガン) と書いてあるんですが (笑), まさに そういう感じで, なかなか厄介な問題ですね。

[嵩] それは土木構造物と建築の違いがあると思うん です。建築の場合は, 室内側は水分の供給がないので, 外側だけの問題ですから…...

[小林］中はいいわけですね。

[嵩］ええ。屋内のコンクリートには, あまり問題は 生じないと思います。

[小林］ただ，基礎はなかなかむずかしい。

[嵩］基礎については, 被害の程度を調べようにも困 難ですし，補修もむずかしい。特に再発防止という意味 からも, 基礎については特に対策を考える必要がありま す。

\section{- 最後に一言}

[小林］ 最後に一言ずつ，この問題についてご感想な りありましたらお願いします。

[内川 密実な高品質のコンクリートとなるように配 合, 設計をし， 入念な施工を行うことは大切なことだと 思います。骨材の最大寸法を大きくすることも, 場合に よっては必要となりましょう。

水が通りやすく透気性のコンクリートでは, アルカリ 骨材反応を起こす他の条件が整った場合に容易に反応が 進行しますし，また，アルカリ骨材反応とは関係なくて も，炭酸化や水酸化による骨材自身の変質によるコンク リートの劣化を起こしやすくなります。

やむをえず反応性の高い骨材を使用する場合には，コ ンクリート中のアルカリ量を減させるために, セメント 中のアルカリ含有量に応じて単位セメント量の上限を定 めることが行われていますが，反応性の高い骨材を用い た場合という前提条件を忘れて, 混和剤を使用して単位 水量を下げ, 強度さえ出ればよいといらことで単位セメ ント量を減らすといらような例を時折見かけますが，コ ンクリートの耐久性といら点からは, 決して賢明な方法 とは申せをせん。中性化も進行しやすくなりますし，鉄 筋の腐食なども起きましょう。

半永久構造物材料としての最も重要な物性の一つであ る耐久性をより一層向上させるためには，耐久性低下の 原因の一つとなっているアルカリ骨材反応によるコンク リートの劣化を防止することは, きわめて重要なことで コンクリート工学 
ありこの目標に向かって 産・官・学共同の研究体制が 組織され, それが有効に機能 することを切に望んでおりま す。

[嵩］この対策について, いま海外の話がありました が,アメリカのいき方とイギ リスのいき方というのは, か なり違いがあるわけです。

アメリカのほうはまだ, 骨 材を規制することによって対 応できるという前提で, それ がだめだったらセメントのア

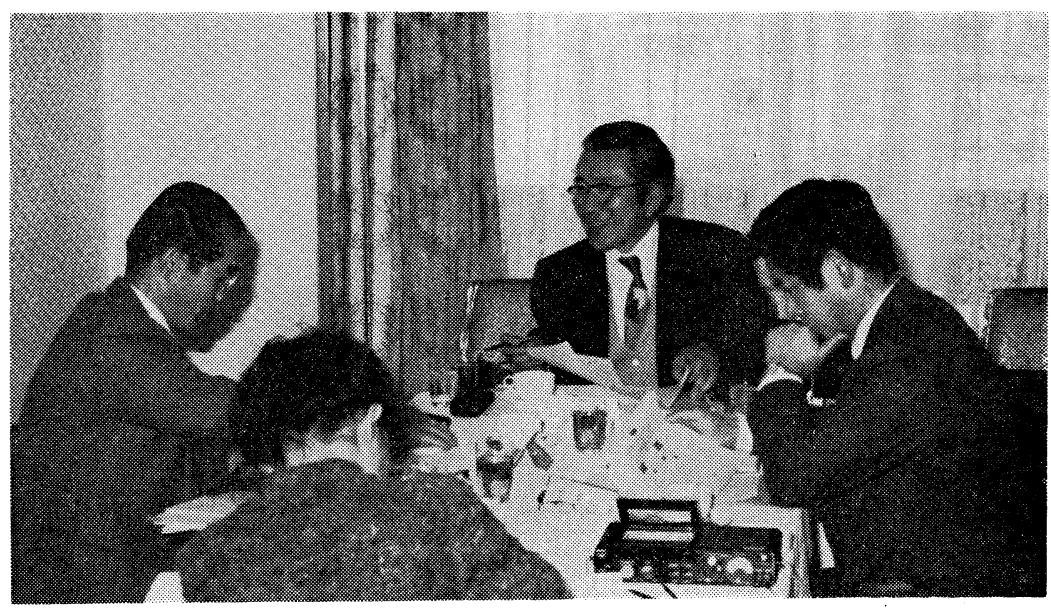
ルカリを下げなさいといらアクションですね。

それ対してイギリスのいき方は，骨材を排除すると いらことは不可能だという前提に立って考えているよう で，しかもイギリスは，セメントのアルカリを規制しな くても，もともと混和材としての高炉スラグ水砕が供給 されていますので, 特に大きな変革をしなくても, それ による対策が可能だという実際的な判断で，いまのよう な C \& CA のガイドが出ているようです。

それと, ヨーロッパでは生コンの普及率がまだ低く, 現場練りコンクリートが多いために, 発注者, ゼネコ ン，コンサルタントなどが骨材の品質に責任を持つとい う体制が残されております。

それに対してわが国は, 生コンが普及し, ダムとか原 子力発電所といった特殊な大プロジェクトを除いては現 場練りコンクリートがなく, 発注者やゼネコンが骨材の 品質に責任を持てる体制にはありません。それにもかか わらず, 生コンの方でも, 大きな工場だけでなく, 零細 な生コン工場も含めて共販制がとられていて, 責任体制 が不明確になっています。現状では, 発注者やゼネコン の側で, ある生コン工場で使用している骨材に問題があ ると分かっても, 共販制度の下では, その工場からの納 品を拒否することができない。ここに大きな問題がある と思います。

それらを考えますと, やはり, 生コンの材料の中の唯 一の工業製品であるセメント側で, ある程度のガードを していただくということが必要になるのじゃないでしょ らか。

特に関西以西で問題になっている今回のアルカリ・シ リカ反応については, 一つの対策だけをとればいいとい らことではなしに, 全体としてどうやったら防げるかと いう判断が必要だろらと思います。

まず，不良骨材を使わない方策というのが必要ですが その網の目を抜けてくるものに対する対策としては, や

はりセメント中のアルカリの低減, あるいはセメントが 無理であるならば, 混和材料としての高炉スラグの使用 によるコンクリート中のアルカリ量の低減を可能にする ということも必要です。また, コンクリートの側の対策 でも, 十分なものについては, 今後は設計段階で, 特に 仕上げを施すとか，そういうことを含めての対策という のが必要であろうと思います。

ですから，コンクリートに関係する業界，コーザーも 含めて，責任のなすり合いではなしに，どらしたら最も 合理的な対策がとり得るかということを考える必要があ ります。

先ほど被害建物をどうするかといら話がありました が，土木構造物でも建て替えというのは困難でしょう が, 特に建築については, 現実に人が住んでる建物を建 て替えるといらのは非常に困難です。また, 実際に建て 替えるということに至らなくとも，美観を損ならという ことは, その建物の財産価值を損ならわけですから, や はり建設に携わる者, あるいはコンクリートの製造に関 係する人たちの共通の責任として, 個別の対応ではなし に, 全体としての対応というのを早く行ら必要がある。 それぞれができる範囲での対策をとることによって， それが全体として効果を発揮するということが重要であ る上思います。

［小林］きょうは，貴重なお話を長時間ありがとらご ざいました。

(1984 年 1 月 27 日/東京平河町・マッヤサロンにて) 